\title{
Attitudes And Assets: An Investigation Of The Causes Of Personal Bankruptcy
}

J. Roberto A. deMagalhaes, (Email: Roberto@cob.tamucc.edu), Texas A\&M University, Corpus Christi Pamela Stokes, Texas A\&M University, Corpus Christi

\begin{abstract}
This descriptive study focuses on Chapter 13 bankruptcy filers in South Texas. Our survey asked respondents to identify the main reasons for the financial problems that lead to declaring bankruptcy. We also asked questions about certain attitudinal factors that may have contributed to their financial difficulties: what income they believed they needed to live comfortably, their opinions about credit card debt, and the relationship between money and happiness. Our study identifies issues that should be considered by creditors, legislators, professional advisors, and educators to help persons avoid bankruptcy.
\end{abstract}

\section{INTRODUCTION}

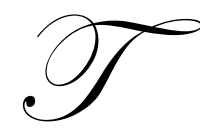

his descriptive study focuses on filers of Chapter 13 bankruptcy in two locations in South Texas: Corpus Christi and Harlingen. Personal bankruptcy merits closer study because it affects many Americans and continues to be debated in the United States Congress. This year, one and a half million bankruptcies are expected to be filed, and an estimated $\$ 40$ billion in debt is expected to be discharged as a result. In view of the expected increase in the numbers of bankruptcy filings, more needs to be known about these debtors: their demographic characteristics, what got them into financial difficulties, their attitudes toward personal financial management, and why they chose bankruptcy protection.

Creditors should attempt to understand the causes of personal bankruptcies that often lead them to write-off amounts that, in the aggregate, are material. This information can be useful to those involved in consumer debt education and to legislators who are considering significant changes to the bankruptcy laws. Attorneys, accountants, and other financial advisors should also stay current on bankruptcy trends even if they are not working directly in this area. A client to whom one provides advice may have to consider filing for bankruptcy protection, or one of the client's customers may be headed for bankruptcy.

The remainder of this paper is organized in the following manner. In the next section we review the relevant literature. The third section discusses the research methodology used. The fourth section presents the results of our survey. Finally, we provide a discussion of conclusions, limitations, and suggestions for future research.

\section{RESEARCH}

Numerous articles have attempted to identify the causes of bankruptcy. We know for instance that persons who have incurred high medical expenses, divorced, or lost a job are more likely to declare bankruptcy (Ian Domwitz and Robert L. Sartain, 1999, J. J. Watson, 1998). Often persons who declare bankruptcy have a higher level of credit card and unsecured debt than those who do not file for bankruptcy (Jean Clements et al., 1999, Ian Domwitz and Robert L. Sartain, 1999). Khasru (1996) noted that many bankruptcies resulted from the inability of low and middleincome homeowners to make their mortgage payments. According to Khasru, many lost their jobs during an economic recession and found themselves overextended on credit card debts. In the same article, Stamford bankruptcy lawyer Francis J. Browne stated that "people who file for bankruptcy have, on average, $\$ 20,000$ in credit card debt. About 30 percent of them own homes. They want to keep their property, so they pay the mortgage but default on credit card 
payment" (B. Z. Khasru, 1996). Our results, presented in this fourth section of this article, corroborate the causes for bankruptcy that have been identified in the literature.

To further explore reasons for personal financial troubles, the financial press and academic researchers have reported extensively on the spending habits of Americans. Many have speculated on the motivations for materialism and overspending, and how they relate to happiness. In 1996, the National Opinion Research Center found that although Americans earned twice as much as they did in 1957, the proportion of persons surveyed identifying themselves as "very happy" declined from 35 to 29 percent (David G Myers and E Diener, 1996). Some conclude that persons overspend to compensate for their insecurity and low self-esteem. Beckman (2002) reports on Robert Arkin's study which found that undergraduate students who are self-doubters compensate by investing in material things. Arkin's research suggests a link between materialism and lower levels of life satisfaction. It is plausible that materialistic values could lead to overspending, indebtedness, and financial difficulties. Watson (1998), for example, examined the relationship among materialistic values, attitudes toward debt, and level of indebtedness, also using student subjects. The study found that subjects with high levels of materialism have a more positive attitude toward debt and spending. Watson's study did not, however, show a significant relationship between materialism and actual debt levels.

Elizabeth Warren, a Harvard Law School bankruptcy expert, offers an alternative explanation as to why many middle-class families may be on the brink of financial disaster. Warren's most recently co-authored book proposes that, contrary to popular belief, two-income middle-class families are not squandering their income on luxuries (Elizabeth Warren and Amelia Warren Tyagi, 2003). The authors refute the idea that most bankruptcy filers are immoral debtors who take advantage of the system. They point out that two-income families are more likely to file for bankruptcy than one-income families, and assert that both incomes are almost entirely spent on necessities such as mortgage and car payments, health costs and educational costs for their children. Most importantly, these families often buy houses they cannot afford in order to live in a neighborhood served by better schools. As a result, they are financially overextended and have no resources to help them deal with emergencies such as the loss of a job or a serious illness. However, it is also clear that many families and individuals handle their finances and lifestyles so they avoid unmanageable debt and related economic problems. The results of this study may help discover what factors might be predictive of one's ability to handle money, and therefore a person's future financial circumstances.

Studies of consumer debt education programs in South Texas suggest that debtors can be effectively taught financial skills and money management behaviors. Stokes (1995) studied the effectiveness of debtor education by surveying Chapter 13 debtors in South Texas. Her research indicated that over 80 percent of those surveyed had used information gained in a debtor education class in subsequent financial management activities. Thirty five percent of those surveyed indicated that their money management skills had improved "very much" while another 45 percent indicated that their money management skills improved somewhat. More specifically, 57 percent of respondents identified the budgeting section of the course as most valuable while 36 percent indicated "goal setting" as most valuable. Stokes and Polansky (1999) studied debtors in bankruptcy in South Texas relative to their economic locus of control, which is the relative degree to which an individual perceives that a reward follows from his behavior rather than being controlled by external forces. They concluded that by modifying participants' locus of control toward an internal orientation leads to more successful money management behavior. Stokes and Benavides (2004) surveyed 153 Chapter 13 filers who were participants in debt education classes from 1998 to 2001. Participants previously had filed for Chapter 13 bankruptcy relief. Their study supports the premise that debt education has encouraging results. Over 80 percent of respondents incorporated their training into their spending behavior while 82 percent reported improved money management skills. Interestingly, 31 percent indicated that "personal planning, values, goals and priorities" were the most useful concepts learned.

Studies of consumer debt education beyond South Texas also suggest that there is positive value in providing debt education and counseling. Several Visa International studies suggest that debt education reduces losses to creditors from consumers in financial distress and improves the money management habits of debtors. A 1996 Visa study recommended better debt education and increasing awareness about alternatives to bankruptcy. In response, Visa implemented procedures to identify cardholder bankruptcy and to screen for abuses in bankruptcy protection. Visa (1999) surveyed 50,000 participants in a credit counseling agency debt management plan. Those who 
successfully completed the debt management plan were found to better manage their finances and avoid bankruptcy than those who did not complete the plan. A Visa (2000) survey of 20,000 debtors who filed for bankruptcy found that most filers wanted more consumer debt education, even years after filing. This indicates receptiveness to educational efforts, which can then be capitalized on to improve financial literacy levels throughout the country.

When considering the information presented in this paper, it is also important to keep abreast of possible changes in bankruptcy legislation. The United States Congress is considering proposed amendments to bankruptcy law that would have serious consequences for debtors, despite forceful opposition from consumer groups. First, some debtors may have to choose Chapter 13 bankruptcy instead of a Chapter 7 bankruptcy due to the inclusion of a means test to determine who can qualify for Chapter 7 . The means test would make it more difficult to file Chapter 7 bankruptcy. Second, the amounts allowed for exempt assets, which are the assets that debtors may keep and still discharge their debts, may be reduced. Creditors are particularly likely to lobby for changes in the homestead exemption in states like Texas and Florida where there is an unlimited homestead exemption. Most importantly for this study, legislative changes may require bankruptcy filers to participate in debtor education (Randall K. Hanson and James K. Smith, 2003).

\section{METHODOLOGY}

To further explore attitudes and behaviors regarding consumer debt, we developed a survey instrument that deals with a variety of issues regarding personal bankruptcy. The questions focused primarily on the relationships between money and happiness, perceptions regarding ability to handle credit, and reasons for filing bankruptcy. We distributed questionnaires to filers of Chapter 13 bankruptcy who attended mandatory 3-hour-long money management classes in 2003-2004. The classes are offered in Harlingen and Corpus Christi, Texas several times a year. The subjects were asked to complete the questionnaires anonymously prior to the beginning of the class. We believe that anonymity helps some individuals answer questions concerning difficult personal circumstances more candidly. By asking the subjects to complete the questionnaires at the beginning instead of at the end of class we guard against the possibility that some answers could be biased by class instruction or course materials. A listing of the questions asked in the survey instrument is shown in Appendix "A" along with the results obtained. We collected nearly 500 completed questionnaires.

Subjects were asked to use a Likert scale of 1 to 5 when answering various questions. Hence, some of the survey variables are ordinal while others are nominal or continuous, as when subjects reported their income. First we generated descriptive statistics. Second, we analyzed the data further by performing Kruskal-Wallis one-way analyses of variance. We chose this non-parametric test since much of this nominal or ordinal data are not normally distributed. This methodology is appropriate because we wished to compare groups based on demographic or ordinal variables to determine if their answers were significantly different. For example, we classified subjects in one of 6 income groups to assess whether minimum household income needed, expressed as a percentage of their current income, differed among income groups. We also analyzed responses of persons according to race/ethnicity, education, and self-rated level of training in financial skills. At the end of the survey we asked several demographic questions.

\section{RESULTS}

The results of the survey are presented in Appendix A. Demographically, approximately 55 percent of the subjects were between the ages of 40 and 59. The majority of subjects are married (66.5 percent). Most subjects are high school graduates and a small minority has even completed post-graduate programs. Seventy-eight percent of subjects are Hispanic/Latin while 15.6 percent are Caucasian/White. This does not surprise us since the financial management classes were held in Corpus Christi and in Harlingen, a predominantly Hispanic part of the Rio Grande Valley of Texas. We compared the answers from Hispanic/Latin subjects in relation to those of the Caucasian/White subjects. We found no significant differences in the answers from these two groups. The mean household income is about $\$ 31,217$ although the 35 percent of subjects earned less than $\$ 20,000$. Fifty-five percent earned $\$ 30,000$ or less annually. 
Regarding their income, 51 percent of subjects thought that their level of income was low. ${ }^{1}$ The least amount our subjects mentioned they need to live comfortably was an average of $\$ 40,894$ which is very close to the median household income in the US, $\$ 41,994$ (Census U.S., 2000). This indicates, on average, about a $\$ 10,000$ gap between actual income and the minimum income subjects perceive they need to live comfortably.

On questions related to their attitude toward such items as happiness, and the importance of money, we found that most subjects were fairly happy (34 percent ranked their happiness as high in question 5), and considered money to be important to their happiness ( 45 percent ranked the importance of money as high in question 6).

Forty-six percent highly agreed in question 7 that when a person is issued a credit card, the issuer believes that person can responsibly handle that amount of credit. Given the fact that credit card debt is the second most common reason for declaring bankruptcy, this is an important finding. This finding is noteworthy considering that approximately 22 percent of respondents rated their level of training in financial skills as high in response to question 9 and that 41 percent rated their financial skills as at least average.

Forty seven percent of subjects were highly satisfied with their employment as indicated in their responses to question 8 .

Regarding "controllable" factors for the financial difficulty, the three most important reasons for the subjects' money problems are: 1) house payments/property taxes, 2) overspending with credit cards, and 3) loans other than home or credit card debt. These are issues that can be addressed through consumer debt education. Other reasons are perhaps less preventable. For example, medical problems and loss of income were also identified as important reasons. However, even if these latter problems are not completely controllable, sound financial management practices, such as maintaining sufficient emergency savings, could mitigate the negative effects of such events.

Table 1 shows the results of our analysis of questions 6 and 7 of the survey. Question 6 asks how important money is to their happiness. Question 7 asks subjects how strongly they agree or disagree with the statement that when a person is issued a credit card the issuer believes that person can responsibly handle the credit. The results of this analysis suggest that there are significant differences among the five groups of subjects based on how important they consider money to be in their lives. The results are significant (Chi-Square: 9.7604; p<.05) and suggest that persons who consider money to be more important in their lives are more likely to believe that credit card issuers have confidence in their debtors to handle credit responsibly. The average rank score to this question was 3.32. Those subjects who ranked money as being more important to their lives, however, tended to agree more strongly with the statement in question 7 and subjects who consider money to be relatively less important in their lives tended not to agree as strongly with the statement in question 7 .

Table 1 - Kruskal-Wallis 1-Way Anova Analysis:

Responsible Handling of Credit Card Debt (Question 7) by Importance of Money (Question 6)

\begin{tabular}{|c|c|c|}
\hline \multicolumn{2}{|c|}{ CCARD by MONEY } \\
\hline Mean Rank & Cases & MONEY $=1$ \\
\hline 198.61 & 22 & MONEY $=2$ \\
\hline 204.96 & 62 & MONEY =3 \\
\hline 226.69 & 172 & MONEY =4 \\
\hline 255.45 & 105 & MONEY $=5$ \\
\hline 251.00 & 107 & \\
\hline
\end{tabular}

\footnotetext{
${ }^{1}$ We refer to responses of 1 and 2 as low, 3 as medium or average, and 4 and 5 as high relative to the Likert scale ranking of 1 to 5 .
} 
Corrected for Ties

\begin{tabular}{|c|c|c|c|c|c|}
\hline Chi-Square & D.F. & Significance & Chi-Square & D.F. & Significance \\
\hline 9.1926 & 4 & .0565 & 9.7604 & 4 & .0447 \\
\hline
\end{tabular}

Description of Subpopulations

\begin{tabular}{|c|c|c|c|c|}
\hline \multicolumn{5}{|c|}{ Summaries of CCARD by Levels of MONEY } \\
\hline $\begin{array}{c}\text { Variable for Entire } \\
\text { Population }\end{array}$ & Value Label & Mean & Std. Dev. & Cases \\
\hline MONEY & 1 & 3.3226 & 1.4781 & 468 \\
\hline MONEY & 2 & 2.8182 & 1.9182 & 22 \\
\hline MONEY & 3 & 2.9839 & 1.5094 & 62 \\
\hline MONEY & 4 & 3.2384 & 1.4614 & 172 \\
\hline MONEY & 5 & 3.5810 & 1.3429 & 105 \\
\hline Total Cases & & 3.5047 & 1.4626 & 107 \\
\hline
\end{tabular}

Therefore, people who ranked the importance of money very high on the scale may be more willing to accept and use credit cards as they perceive (or rationalize) the issuers have determined they can responsibly handle the approved level of credit. It would be interesting to know if these individuals also have a more external locus of control, as may be indicated by their apparent deferral to the credit companies' determination. This finding also indicates a widespread reliance on and trust in credit card companies' decisions to extend credit. This trust may prove to be misplaced for many individuals, and ultimately risky to their financial health. Financial education may be able to prevent such overextension of credit by teaching individuals how to responsibly determine appropriate borrowing limits.

Table 2 shows the results of our analysis of data from questions 1 and 3 . We first calculated the variable NEEDPERCENT ${ }^{2}$, which is a measure of the gap between actual income and the least amount of income respondents felt they needed to live comfortably. We then placed the subjects in six income categories (INCOMELEVEL 1 to 6 ) to determine whether NEEDPERCENT differs significantly among income groups. The results are significant (ChiSquare: 93.78; $\mathrm{p}<.01$ ), showing that NEEDPERCENT is much greater for subjects who earned less than $\$ 20,000$ annually. These results suggest that there is an inverse relationship between income level and NEEDPERCENT. That is, lower income groups had larger, negative NEEDPERCENT measures.

Table 2 - Kruskal-Wallis 1-Way Anova Analysis:

Least Amount of Income Needed (Expressed as a Percentage of Current Income by Levels of Income (Questions 1 and 3)

\begin{tabular}{|c|c|c|}
\hline \multicolumn{3}{|c|}{ NEED PERCENT by INCOME LEVEL } \\
\hline Mean Rank & Cases & INCOME LEVEL $=1$ \\
\hline 152.68 & 157 & INCOME LEVEL $=2$ \\
\hline 234.23 & 94 & INCOME LEVEL $=3$ \\
\hline 251.07 & 75 & INCOME LEVEL $=4$ \\
\hline 252.80 & 52 & INCOME LEVEL $=5$ \\
\hline 313.96 & 41 & INCOME LEVEL $=6$ \\
\hline 331.84 & 28 & \\
\hline
\end{tabular}

\footnotetext{
${ }^{2}$ NEEDPERCENT was calculated from answers to questions 1 and 3. NEEDPERCENT $=($ actual household income - least amount needed $) /$ actual household income.
} 
Corrected for ties

\begin{tabular}{|c|c|c|c|c|c|}
\hline Chi-Square & D.F. & Significance & Chi-Square & D.F. & Significance \\
\hline 93.7254 & 5 & .0000 & 93.7882 & 5 & .0000 \\
\hline
\end{tabular}

Description of Subpopulations

\begin{tabular}{|c|c|c|c|c|}
\hline \multicolumn{2}{|c|}{ Summaries of NEED PERCENT by Levels of INCOME LEVEL } \\
\hline $\begin{array}{c}\text { Variable for Entire } \\
\text { Population }\end{array}$ & Value Label & Mean & Std. Dev. & Cases \\
\hline & & .5958 & 1.9187 & 447 \\
\hline INCOME LEVEL & 1 & -1.2663 & 3.0673 & 957 \\
\hline INCOME LEVEL & 2 & -.3472 & .5644 & 75 \\
\hline INCOME LEVEL & 3 & -.2681 & .4818 & 52 \\
\hline INCOME LEVEL & 4 & -.2603 & .3805 & 41 \\
\hline INCOME LEVEL & 5 & -0.339 & .3245 & 28 \\
\hline INCOME LEVEL & 6 & .0056 & .2995 & 486 \\
\hline Total Cases & & & & \\
\hline
\end{tabular}

It is important to note that the income group earning less than $\$ 20,000$ per year (INCOMELEVEL 1) has a mean NEEDPERCENT of -1.26 percent. Thus, on average, persons in this income level believe they need nearly 126 percent more income than they currently earn to live comfortably. The gap between actual and perceived income needed is large for these individuals, and may explain why persons in this income group are facing financial difficulties. They may be overextending themselves with credit spending to maintain a lifestyle based on their perceived needs. Alternatively, particularly for the lowest income levels, their income may simply be too low to afford the basic necessities of life. For individuals on the higher end of the income spectrum there is not as wide of a gap between actual and perceived income needed. Table 2 suggests that the higher the income, the smaller the gap between actual and perceived income needed. In fact those at the highest income category did not indicate a gap between actual and perceived income needed at all.

These results can be used to educate consumers to define their needs more realistically in line with their annual incomes. Debt educators can focus their efforts on counseling that more closely fits the needs of individual clients, such as providing model budgets for various income levels and discussing cost-saving techniques for lower income individuals.

Table 3 shows the results of our analysis of subjects' ranking of the importance of money to their happiness (question 6) in relation to their ranking of how happy they said they were (question 5). We wanted to know if there was any relationship between happiness and the importance of money. The results show that there is an inverse relationship between being happy and ranking income or wealth highly in one's life. The category of respondent who answered they were least happy (HAPPY category 1) rated money as being most important in their lives. This result is consistent with the research by Myers (1996) which suggests that increased income does not lead to greater happiness. This information can be utilized by financial educators to persuade people that money cannot buy happiness, and that individuals can be happy without a lot of material wealth or possessions. Individuals may then be encouraged to discover more valid means of attaining satisfaction and contentment which will not be financially destructive. 
Table 3 - Kruskal-Wallis 1-Way Anova Analysis:

Importance of Money (Question 6) by Happiness (Question 5)

\begin{tabular}{|c|c|c|}
\hline \multicolumn{2}{|c|}{ MONEY by HAPPY } \\
\hline Mean Rank & Cases & HAPPY $=1$ \\
\hline 286.62 & 53 & HAPPY $=2$ \\
\hline 254.04 & 85 & HAPPY $=3$ \\
\hline 229.77 & 164 & HAPPY $=4$ \\
\hline 215.58 & 97 & HAPPY $=5$ \\
\hline 208.24 & 69 & \\
\hline & & \\
\hline
\end{tabular}

Corrected for ties

\begin{tabular}{|c|c|c|c|c|c|}
\hline Chi-Square & D.F. & Significance & Chi-Square & D.F. & Significance \\
\hline 14.3457 & 4 & .0063 & 15.5002 & 4 & .0038 \\
\hline
\end{tabular}

Description of Subpopulations

\begin{tabular}{|c|c|c|c|c|}
\hline \multicolumn{5}{|c|}{ Summaries of MONEY by Levels of HAPPY } \\
\hline $\begin{array}{c}\text { Variable for Entire } \\
\text { Population }\end{array}$ & Value Label & Mean & Std. Dev. & Cases \\
\hline & & .4530 & 1.1278 & 468 \\
\hline HAPPY & 1 & 3.8868 & 1.2658 & 53 \\
\hline HAPPY & 2 & 3.6118 & 1.2257 & 85 \\
\hline HAPPY & 3 & 3.4329 & .9537 & 164 \\
\hline HAPPY & 4 & 3.2887 & 1.0202 & 97 \\
\hline HAPPY & 5 & 3.2029 & 1.3126 & 69 \\
\hline Total Cases & & & & \\
\end{tabular}

\section{CONCLUSIONS}

This study identifies specific behavioral issues related to money management that should be considered, especially by providers of consumer debt education and counseling. First, there is a clear need for training in basic money management skills, even though 63 percent of those we surveyed rated their level of training in financial skills as average or better. Thirty two percent of the respondents, for example, strongly agree that credit card issuers think they can handle the debt responsibly if they are issued a credit card, even though credit card debt was a major cause of filing for bankruptcy. Second, consumer debt education should emphasize ways of planning for and managing the more controllable types of debt that are major factors in filing for bankruptcy. An emphasis on the importance of savings and avoiding overextension of credit would go a long way toward this goal. Third, those at the lower income groups should be educated in budgeting methods and cautioned that the gap between actual income and income "needed" should not be bridged by consumer loans and credit card debt. Finally, debtors should be counseled that they can become happier people by taking control of their finances.

This study has some limitations that should be noted. First, we purposely limited the scope of the study to the South Texas region. One may not be able to generalize from these results to the rest of the country. Second, we surveyed only filers of Chapter 13 bankruptcy protection. A survey of people who have not filed for bankruptcy would provide valuable information for a contrasting population. Third, we identified major factors that contribute to bankruptcy but we made no attempt to measure how much debt was discharged. In a future study we intend to extend this study by exploring whether reasons for bankruptcy differ among demographic groups by age, education, or ethnicity. 


\section{APPENDIX A}

\section{Descriptive Statistics ${ }^{3}$}

1. Annual Household Income
Mean:
$\$ 31,217$
Standard Deviation: $\quad \$ 18,653$

\begin{tabular}{|c|l|c|}
\hline Income Groups & Annual Income & Percent of Subjects \\
\hline 1 & $<\$ 20,000$ & $35 \%$ \\
\hline 2 & $\$ 20,001-\$ 30,000$ & $20 \%$ \\
\hline 3 & $\$ 30,001-\$ 40,000$ & $16 \%$ \\
\hline 4 & $\$ 40,001-\$ 50,000$ & $11 \%$ \\
\hline 5 & $\$ 50,001-\$ 60,000$ & $9 \%$ \\
\hline 6 & $\$ 60,000$ and over & $6 \%$ \\
\hline
\end{tabular}

2. How subjects rated their level of income:

far too low
\begin{tabular}{|c|c|c|c|c|}
\hline $\mathbf{1}$ & $\mathbf{2}$ & $\mathbf{3}$ & $\mathbf{4}$ & $\begin{array}{c}\text { more than } \\
\text { sufficient }\end{array}$ \\
\hline $19 \%$ & $32 \%$ & $40 \%$ & $5.3 \%$ & $\mathbf{5}$ \\
\hline
\end{tabular}

3. The least amount subjects need to live comfortably:

Mean:

$\$ 40,894$

Standard Deviation: $\$ 22,323$

4. The least amount a couple (with no children) need to live:

Mean:

$\$ 39,110$

Standard Deviation: $\$ 34,060$

5. How happy subjects rated themselves:

$\begin{gathered}\text { very } \\
\text { unhappy }\end{gathered}$
\begin{tabular}{|c|c|c|c|c|}
\hline $\mathbf{1}$ & $\mathbf{2}$ & $\mathbf{3}$ & $\mathbf{4}$ & $\begin{array}{c}\text { very } \\
\text { happy }\end{array}$ \\
\hline $11 \%$ & $22 \%$ & $34 \%$ & $20 \%$ & $\mathbf{5}$ \\
\hline
\end{tabular}

6. The importance of money (income or wealth) to their happiness:

$\begin{gathered}\text { not at all } \\
\text { important }\end{gathered}$
\begin{tabular}{|c|c|c|c|c|}
\hline $\mathbf{1}$ & $\mathbf{2}$ & $\mathbf{3}$ & $\mathbf{4}$ & $\begin{array}{c}\text { very } \\
\text { important }\end{array}$ \\
\hline $5 \%$ & $13 \%$ & $36 \%$ & $22 \%$ & $\mathbf{5}$ \\
\hline
\end{tabular}

\footnotetext{
${ }^{3}$ Percentages may not add up to 100 percent due to lack of responses to some questions.
} 
7. If a person is issued a credit card it means the issuer believes that person can responsibly handle that amount of credit:

$\begin{gathered}\text { strongly } \\
\text { agree }\end{gathered}$
\begin{tabular}{|c|c|c|c|c|}
\hline $\mathbf{1}$ & $\mathbf{2}$ & $\mathbf{3}$ & $\mathbf{4}$ & $\begin{array}{c}\text { strongly } \\
\text { disagree }\end{array}$ \\
\hline $18 \%$ & $11 \%$ & $23 \%$ & $14 \%$ & $\mathbf{5}$ \\
\hline
\end{tabular}

8. $\quad$ Satisfaction with employment:

$\begin{gathered}\text { very } \\
\text { satisfied }\end{gathered}$
\begin{tabular}{|c|c|c|c|c|}
\hline $\mathbf{1}$ & $\mathbf{2}$ & $\mathbf{3}$ & $\mathbf{4}$ & $\begin{array}{c}\text { very } \\
\text { dissatisfied }\end{array}$ \\
\hline $10 \%$ & $9 \%$ & $24 \%$ & $22 \%$ & $\mathbf{5}$ \\
\hline
\end{tabular}

9. Ranking of level of training in financial skills:

$\begin{aligned} & \text { very } \\
& \text { low }\end{aligned}$
\begin{tabular}{|c|c|c|c|c|}
\hline $\mathbf{1}$ & $\mathbf{2}$ & $\mathbf{3}$ & $\mathbf{4}$ & $\begin{array}{c}\text { very } \\
\text { high }\end{array}$ \\
\hline $14 \%$ & $18 \%$ & $41 \%$ & $\mathbf{5}$ \\
\hline
\end{tabular}

10. Three most important reasons for the subjects' money problems:

\begin{tabular}{|c|c|c|c|}
\hline Reasons & Most Important & $\begin{array}{c}2^{\text {nd }} \text { Most } \\
\text { Important }\end{array}$ & $\begin{array}{c}3^{\text {rd }} \text { Most } \\
\text { Important }\end{array}$ \\
\hline House payments/property taxes & $35.3 \%$ & $14.0 \%$ & $9.3 \%$ \\
\hline Overspending with credit cards & 19.3 & 14.6 & 10.8 \\
\hline Loans other than home or credit card debt & 6.7 & 17.5 & 15.4 \\
\hline Business problems (sole proprietor or family business) & 6.7 & 2.8 & 1.6 \\
\hline Medical or health problems & 8.0 & 22.4 & 20.9 \\
\hline Loss of a job/loss of income from job & 11.3 & 14.0 & 18.6 \\
\hline Legal problems & 1.3 & 4.2 & 4.7 \\
\hline Family problems (divorce, death of family member, etc.) & 6.0 & 4.2 & 10.9 \\
\hline Income taxes (I.R.S.) & 2.7 & 6.3 & 3.9 \\
\hline Other (please specify) & 2.7 & & 3.9 \\
\hline
\end{tabular}

11. Gender: Male $45.1 \%$, Female $53.3 \%$

12. Age:

\begin{tabular}{|c|c|}
\hline Age Group & Percent of Subjects \\
\hline Under 20 & $0.2 \%$ \\
\hline $20-29$ & 12.6 \\
\hline $30-39$ & 23.3 \\
\hline $40-49$ & 32.3 \\
\hline $50-59$ & 22.0 \\
\hline $60-69$ & 0.7 \\
\hline 70 and over & 1.9 \\
\hline
\end{tabular}


13. Marital Status

\begin{tabular}{|c|c|}
\hline Marital Status & Percent of Subjects \\
\hline Married & $66.5 \%$ \\
\hline Single & 11.1 \\
\hline Living with partner but not married & 6 \\
\hline Separated & 8 \\
\hline
\end{tabular}

14. Occupation: various occupations listed; mostly nonprofessional status.

15. Average number of dependents in the household: 2.3

16. Highest level of education:

\begin{tabular}{|c|c|}
\hline Level of education & Percent of Subjects \\
\hline Some high school & $17.5 \%$ \\
\hline High school of GED & 31.5 \\
\hline Some college & 33.3 \\
\hline Completed college & 8.8 \\
\hline Some post-graduate & 1.9 \\
\hline Completed post-graduate & 1.9 \\
\hline
\end{tabular}

17. Race/ethnicity

\begin{tabular}{|l|l|}
\hline Race Ethnicity & Percent of Subjects \\
\hline African American / Black & $1.4 \%$ \\
\hline Caucasian / White & 15.6 \\
\hline Native American & 0.6 \\
\hline Asian & 0.4 \\
\hline Hispanic / Latin & 78 \\
\hline Other & 1.2 \\
\hline
\end{tabular}

\section{REFERENCES}

1. Beckmann, Lacey. “One More Thing Money Can't Buy”, Psychology Today. Sussex Publishers Inc., 2002, 16.

2. Clements, Jean; Johnson, Diane; Michelich, Kathy and Olinsky, Christine F. "Characteristics of Bankruptcy Filers: Implications for Educators". Journal of Family and Consumer Science, 1999, 91(4), pp. 71-74.

3. Domwitz, Ian and Sartain, Robert L. "Determinants of the Consumer Bankruptcy Decision". Journal of Finance, 1999, 54(1), pp. 403-20.

4. Hanson, Randall K. and Smith, James K. "Bankruptcy Law for Accountants". The National Public Accountant, 2003, (Feb/Mar), pp. 4.

5. Khasru, B. Z. "Personal Bankruptcies on the Increase as Stigma Fades". Fairfield County Business Journal, 1996, 35(21), pp. 9, 3/8p.

6. Myers, David G and Diener, E. “The Pursuit of Happiness”. Scientific American, 1996, 274(5), pp. 70-73.

7. Stokes, Pamela. "Moving from Bankruptcy to Solvency: An Educational Experiment That Works". Business Credit, 1995, (June), pp. 20-25.

8. Stokes, Pamela and Benavides, Adolfo. "Force or Free Will? A Comparative Analysis of Mandatory Versus Voluntary Debtor Education”. Journal of Ethical And Regulatory Issues, 2004, Forthcoming (September). 
9. Stokes, Pamela P and Polansky, Sharon. "Shifting the Economic Locus of Control: Improving Financial Decision-Making in High-Risk Populations". Academy of Accounting and Financial Studies Journal, 1999, 3(1), pp. 95-101.

10. U.S., Census. "U.S. Summary: Census 2000 Profile”, Washington, D.C.: United States Census Bureau, 2000, 1-6.

11. Visa. "Consumer Bankruptcy: Causes and Implications: Visa/Wefa White Paper", 1996.

12. _ _Credit Counseling Debt Management Plan Analysis: Visa White Paper". 1999.

13. —. "Life after Bankruptcy Study: Visa White Paper". 2000.

14. Warren, Elizabeth and Tyagi, Amelia Warren. The Two-Income Trap: Why Middle Class Mothers and Fathers Are Going Broke. New York: Basic Books, 2003.

15. Watson, J. J. "Materialism and Debt: A Study of Current Attitudes and Behaviors". Advances in Consumer Research, 1998, 25(1), pp. 203-07.

\section{NOTES}


NOTES 